\title{
特集：疾患の制御一臨床から免疫へ一
}

総説

\section{炎症増強因子としての TREM-1}

\author{
村上洋介, 上阪 等
}

\section{Triggering receptor expressed on myeloid cells-1 as an inflammation amplifier.}

\author{
Yousuke MuraKAMI and Hitoshi KOHSAKA \\ Dearptment of Medicine and Rheumatology, Graduate school of Medicine, Tokyo Medical and Dental University.
}

(Received June 1, 2009)

summary

Triggering receptor expressed on myeloid cells (TREM) -1 is inducible on monocyte/macrophages and neutrophils and accelerates tissue destruction by propagating inflammatory responses in diseases related to bacterial infection. Its blockade suppressed fatal immune responses in mice models of sepsis without impairing the host defense. However, the influence of TREM-1 on non-bacterial diseases was not elucidated. We describe here that TREM-1 expression was upregulated by prostaglandin $(\mathrm{PG}) \mathrm{E}_{2}$ as well as lipopolysaccharide. Activation of TREM-1 expressed on $\mathrm{PGE}_{2}-$ pretreated peripheral blood mononuclear cells by an agonistic TREM-1 mAb significantly enhanced the production of TNF $\alpha$. Indeed, monosodium urate monohydrate (MSU) crystals induced TREM-1 expression in vitro and in vivo. MSU crystals and an anti-TREM-1 agonistic antibody synergistically increased the production of interleukin- $1 \beta$ compared with stimulation with the crystals alone. Furthermore, TREM-1 was expressed on CD14 + cells in rheumatoid synovial tissue and synovial macrophages from mice with collagen-induced arthritis (CIA). Blockade of TREM-1 ameliorated CIA without affecting $\mathrm{T}$ cell and $\mathrm{B}$ cell immune responses to the inducing antigen. These results provide evidence that TREM-1 may contribute the development of non-microbial inflammatory diseases through the enhancement of inflammatory responses.

Key words_-TREM-1; rheumatoid arthritis; macrophage; inflammation

\section{抄 録}

Triggering receptor expressed on myeloid cells (TREM)-1 は，ミエロイド系細胞に発現するレセプターで，TLR と協調的に働くことにより，炎症反応を増強する特徵を有している．リガンドは不明であるが，TREM-1 細胞外 ドメインに IgG-Fc を融合させた TREM-1-Igによって TREM-1 の働きを阻害すると，敗血症などの感染症からマ ウスを保護することができる。これらのことから TREM-1 阻害は感染症制御に有用であることがわかってきた. 一方，微生物の関与しない炎症性疾患について TREM-1 の作用は不明であった。我々は TREM-1の発現は TLR リガンドだけでなく $\mathrm{PGE}_{2}$ や尿酸結晶によって誘導されることを認めた。 また，TREM-1 は尿酸結晶誘発性炎症 の炎症反応を増強する作用も見出した。ささらに TREM-1 は自己免疫疾患である関節リウマチゃその動物モデル （CIA）においても発現が認められ，CIAにおいてTREM-1 を阻害すると，関節炎は著明に改善された．以上のこ とから，TREM-1 が微生物以外の炎症性疾患の有用な治療標的分子となりうることを明らかにした.

\section{I.はじめに}

マクロファージや好中球などのミエロイド系細胞

は，免疫系に重要な役割を果たしている．これらミ エロイド系細胞の分化や活性化は細胞膜上および細 胞内のレセプターがリガンドを認識することで制御 されている. そのようなレセプターは大きく二つに

東京医科歯科大学大学院膠原病 - リウマチ内科学
大別される。一つは，Toll-like receptor（TLR）を はじめとした様々な構造パターン認識レセプターと 呼ばれる分子群で, 微生物を感知すると強力な炎症 反応を発動する。これにより，ミエロイド系細胞は 細菌をはじめとした微生物に対する生体防御機能を 発揮する.もう一つのレセプターとして, interferon (IFN) $\gamma$ セて゚ターが挙げられる. IFN $\gamma$ 自身 はミエロイド系細胞を活性化しないが，TLR から のシグナルを増幅するなど免疫反応の強度を調節す 
る役割を担っていると考えられている. 本稿では, 炎症の強度を調節する分子の一つである Triggering receptor expressed on myeloid cells (TREM) -1 に着 目し，その発現制御機構および炎症性関節炎におけ る働きを紹介する。

\section{TREM-1 とは}

TREM-1 は immunoglobulin superfamily に属す るレセプターで, 単球/マクロファージ, 好中球の ミエロイド系細胞に発現が限局している．との発現 は Lipopolysaccharide (LPS) をはじめとしたTLR リガンドなどの微生物産物によって強く誘導され $る^{1,2)}$. 細胞内に immunoreceptor tyrosine-based activation motief（ITAM）を有しており，DAP12を 介して細胞内にシグナルを伝達する（図 1）. TREM-1 に対するアゴニスト抗体で刺激すると， tumor necrosis factor (TNF) $\alpha$ や interleukin (IL) -1 などの炎症性サイトカイン, macrophage chemoattractant protein $(\mathrm{MCP})-1$ などのケモカイン, 細胞 接着分子などの表面分子の発現が誘導される ${ }^{1)}$. たTREM-1 の大きな特徵として, TLR や Nod-like receptors と協調して炎症反応を飛躍的に増強する 作用がある（図 1 $)^{1,3}$ ，つまり，TREM-1 は炎症反 応の強度を決定する役割を果たしている.

TREM-1 のリガンドは未だ不明であるが，ヒト やマウスの敗血症に抢いて, TREM-1 の発現がミ エロイド系細胞上に誘導されることが数多く報告さ

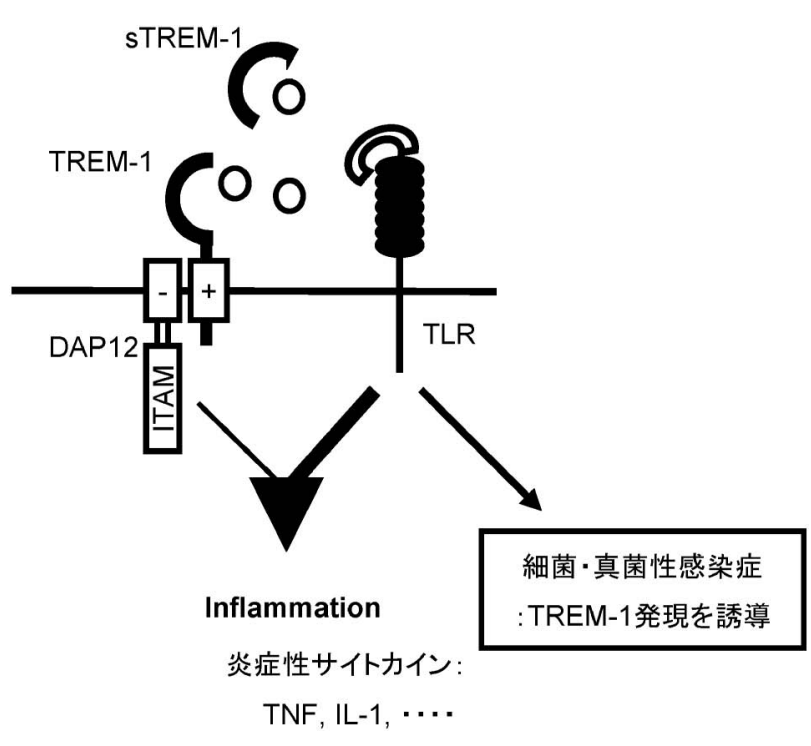

図 1 TREM-1 と TLR とのかかわり

TREM-1 は TLR の刺激により発現が誘導される。 また， TREM-1 は ITAM モチーフをもつ DAP12を介してシグナ ルを伝達し, TLR からの炎症反応を増強する作用を有する.
れている. また, 可溶型 TREM-1 も存在してお り，これは膜型 TREM-1 が metalloproteinase によ り切断されたものである.この可溶型 TREM-1 は, 敗血症の患者の血清や肺胞洗浄液中に高濃度に 検出され，感染症のマーカーとして有用であること が報告されている4).

敗血症の病態では, TREM-1 は増悪因子として 働いており，事実 in vivoに抢いて，TREM-1の細 胞外ドメインと $\mathrm{IgG}-\mathrm{Fc}$ 部分の融合タンパク （TREM-1-Ig）やリガンドが結合すると予想される 合成ペプチドを投与すると，エンドトキシンショッ クや敗血症からマウスを保護することが明らかとな っている5,6).この TREM-1 阻害効果は, 前投与だ けでなく，LPS 投与から 4 時間後においても TREM-1 阻害の効果が認められ，これまでに報告 されたエンドトキシンショックの実験の中でも, 最 も遅く治療を開始して効果のあった分子である。こ れら TREM-1 阻害では TNF $\alpha$ や IL-1 $\beta$ の産生は減 弱するが, 細菌のクリアランスは障害されない程度 の炎症状態は維持されると考えられている。また， 腸内細菌叢が病態形成に重要な役割を果たしている 腸炎モデルにおいても，TREM-1 阻害は有効であ ることが示されている77. 以上のことから，

TREM-1 の活性化は微生物感染の炎症反応を増幅 することで，ある局面においては生体に不利益に働 いていることが考えられている.

\section{Prostaglandin $\mathrm{E}_{2}\left(\mathrm{PGE}_{2}\right)$ による TREM-1 の} 制御

$\mathrm{PGE}_{2}$ は cyclooxygenase (COX) の働きにより合 成される脂質メディエーターの一種で, LPSをは じめとする TLR リガンドにより in vitro, in vivo で その合成が誘導される. $\mathrm{PGE}_{2}$ は炎症・抗炎症に働 くことが報告されており，多彩な機能を有している が，TREM-1 発現における $\mathrm{PGE}_{2}$ の作用は不明で あった。我々は, TREM-1 発現における $\mathrm{PGE}_{2}$ の 作用を検討し, 以下の知見を得た ${ }^{8)}$.

マウスマクロファージおよびヒト末梢血単核球を $\mathrm{PGE}_{2}$ で刺激すると TREM-1 の発現上昇が認めら れた（図 2A)，このときマウスマクロファージに 発現する他のPGレセプターのリガンドを投与して も TREM-1の発現誘導は観察されなかった。この ことから, PG の中でも $\mathrm{PGE}_{2}$ が特異的に TREM-1 の発現を制御していると考えられた。前述の通り, LPS は COX を介して $\mathrm{PGE}_{2}$ の合成を誘導している 


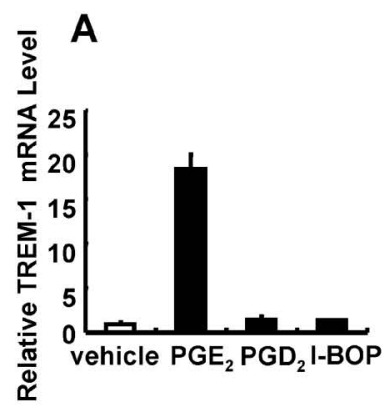

B
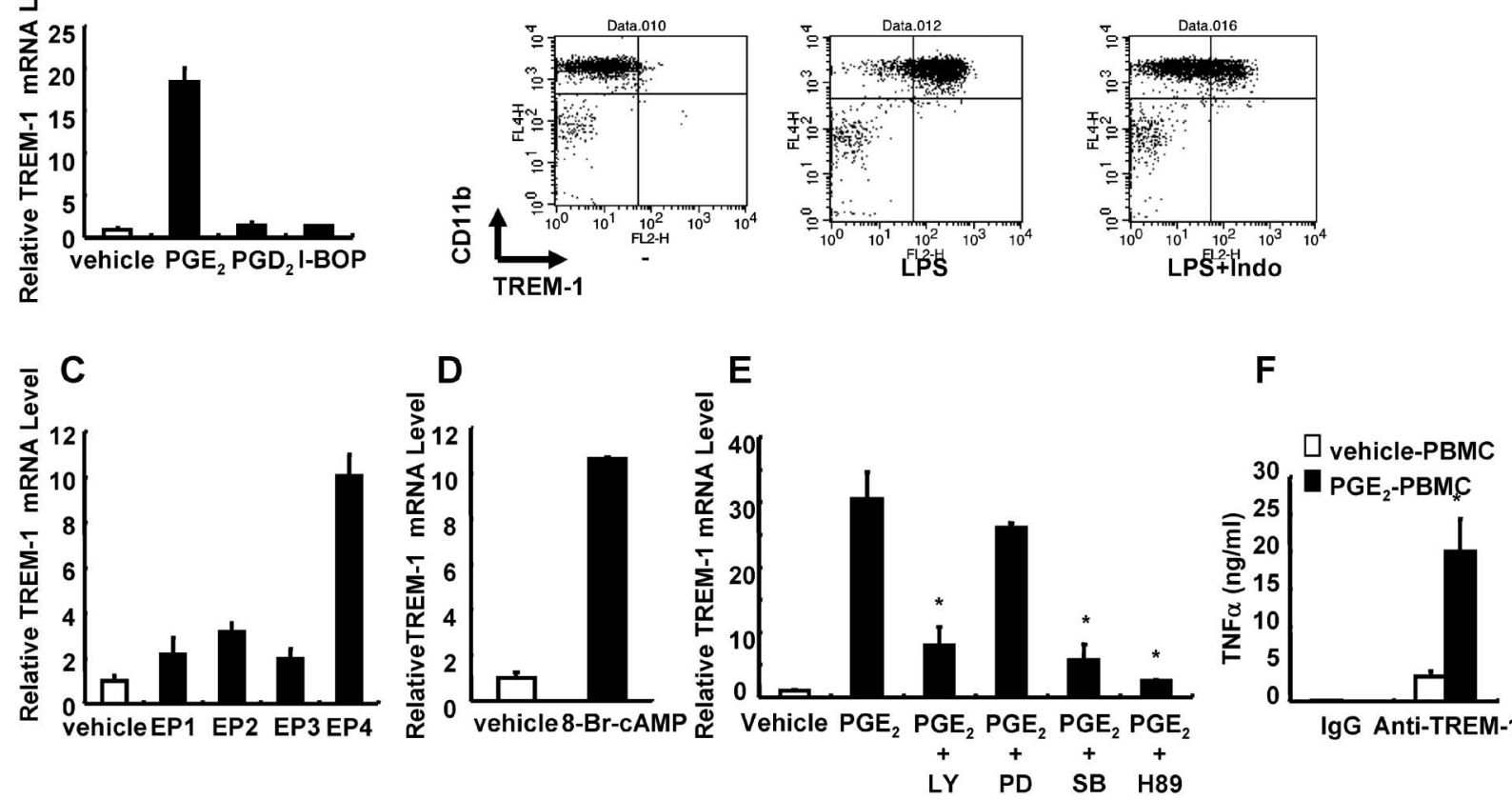

IgG Anti-TREM-1

図 $2 \quad \mathrm{PGE}_{2}$ による TREM-1 発現の制御

A. マクロファージを PGs で刺激し TREM-1 の発現を定量的 PCR で解析. B. LPS 誘導 TREM-1 発現に抢ける COX 阻害剂 (Indomethacin: indo) の影響を flow cytometry で解析. C. PGE 2 レセプターアンタゴニストで刺激し, TREM-1の発現を定量的 PCR で解析. D. cAMP で刺激し, 発現を定量的 PCR で解析. E. キナーゼ阻害剂でマクロファージを処理し, PGE 誘導 $^{2}$ TREM-1 発現に及ぼす影響を定量的 PCR で解析. LY: PI3K 阻害剂, PD: ERK 阻害剂, SB: p38MAPK 阻害剂, H89: PKA 阻害 剂. F. PGE 2 処理した末梢血単核球をアゴニスト TREM-1 抗体で刺激し，TNF $\alpha$ の産生を ELISA で測定.

ことから，LPS による TREM-1 誘導は $\mathrm{PGE}_{2}$ を介 していることが想定される．実際，COX阻害剂存 在下でマウスマクロファージを刺激すると， TREM-1の発現は顕著に阻害された（図 2B）。つ まり，LPS 誘導 TREM-1 発現は COX を介して $\mathrm{PGE}_{2}$ によって誘導されていることが明らかになっ た.さらに TREM-1の発現制御機構について検討 を行うと， $\mathrm{PGE}_{2}$ はレセプターである $\mathrm{EP} 1$ から EP4 のうちEP4 を介して TREM-1 の発現を誘導す ることを認めた（図 2C)。EP4 は細胞内の cAMP 濃度を上昇させ，PKA，p38MAPK，PI3K，ERKの 活性化を誘導することが明らかとなっている。そこ で， cAMPアナログを投与するとマウスマクロフ アージの TREM-1の発現は誘導された（図 2D).

さらに PKA, p38MAPK, PI3K の阻害剤は PGE $_{2}$ 誘導 TREM-1 発現を阻害した（図 $2 \mathrm{E}$ )。以上の 結果加 $, \mathrm{PGE}_{2} \rightarrow \mathrm{EP} 4 \rightarrow \mathrm{cAMP} \rightarrow \mathrm{PKA}, \mathrm{p} 38 \mathrm{MAPK}$, $\mathrm{PI} 3 \mathrm{~K} \rightarrow \mathrm{TREM}-1$ 発現誘導，のシグナルにより TREM-1 の発現が制御されていると考えられる. $\mathrm{PGE}_{2}$ により発現が誘導される TREM-1 が機能的 に働くか検討するため，ヒ下末梢血単核球を $\mathrm{PGE}_{2}$ で前処理し，アゴニスト TREM-1 抗体で刺激する
と,アゴニスト抗体単独と比較して $\mathrm{PGE}_{2}$ を前処理 した細胞では $\mathrm{TNF} \alpha$ の産生が顕著に誘導された (図 $2 \mathrm{~F})$ ）このことから， $\mathrm{PGE}_{2}$ によって誘導され る TREM-1 は機能的に作用していることが考えら れる. $\mathrm{PGE}_{2}$ は様々な炎症局面において放出される 分子であり， $\mathrm{PGE}_{2}$ を介して TREM-1 が誘導さ れ，炎症応答に関与していることが考えられる。

\section{IV． 痛風性関節炎における TREM-1 の関与}

痛風性関節炎は関節腔内に尿酸結晶が沈着し, 好 中球を主体とする著明な炎症性細胞浸潤が認められ る疾患である，尿酸結晶はTLR $2 / 4$ に認識され， Myd88 依存的にシグナルを伝達すると報告があ る。一方，TLR 非依存的に Myd 88 を介するという 報告もある. 何れにせよ，少なくとも尿酸結晶は Myd88 を介して, 炎症反応を惹起しているものと 考えられる。 また，尿酸結晶が Myd88を介して TREM-1 の発現を誘導し, 痛風性関節炎の病態を 制御している可能性も考えられる。そこで我々は, 尿酸結晶誘発性炎症に扮ける TREM-1 の作用につ いて検討し，以下の知見を得た ${ }^{9)}$.

マウスマクロファージを尿酸結晶で刺激すると 
A

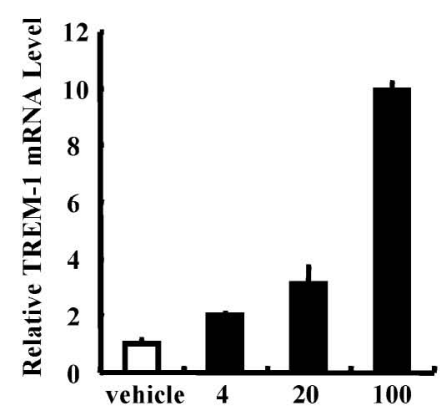

尿酸結晶 $(\mu \mathrm{g})$
B

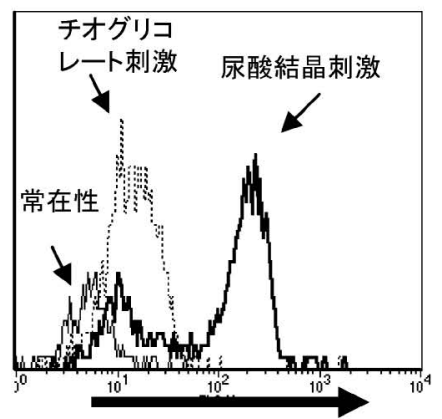

TREM-1

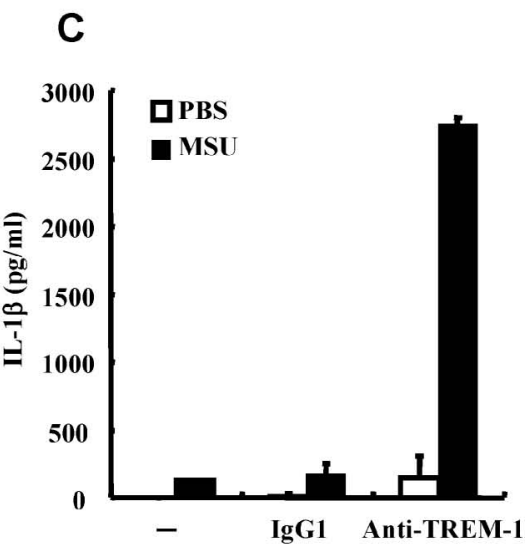

IgGI Anti-TREM-1

図 3 尿酸結晶誘発性炎症に扔けるTREM-1の発現

A. マクロファージを尿酸結晶で刺激し, TREM-1の発現を定量的 PCR で解析. B. マウス空気囊胞に尿酸結晶を投与し, 浸 潤した細胞における TREM-1 の発現を flow cytometry で解析. C. 尿酸結晶とアゴニスト TREM-1 抗体もしくはアイソタイプ抗 体でマクロファージを刺激し, IL- $1 \beta$ の産生を ELISA で測定.

TREM-1 の発現が強く誘導された（図 3A）。尿酸 結晶によるTREM-1 の発現誘導も LPS による TREM-1 発現誘導と同様に $\mathrm{PGE}_{2}$ 依存的であっ た。また，in vivoに打いて尿酸結晶誘発性炎症モ デルを作製するため，マウス背部に空気囊胞を構築 し，尿酸結晶を投与すると，浸潤細胞には TREM1 の発現が顕著に誘導されることが flow cytometry によって観察された（図 3B)，可溶型 TREM-1も 囊胞洗浄液中から検出された。ささらに発現誘導され た TREM-1 が機能的かを検討したところ，尿酸結 晶とアゴニスト TREM-1 抗体による共刺激は，そ れぞれ単独の刺激と比較して，マウスマクロファー ジからの IL-1 $1 \beta$ の産生を相乗的に誘導することが 観察された（図 3C). 以上の結果から，尿酸結晶誘 発性炎症に括いて, TREM-1 は炎症の惹起もしく は増悪に関与していると示唆された。今後は実際に in vivo に打ける TREM-1 阻害が尿酸結晶誘発性炎 症を抑制するかを検討する予定である。

\section{RA における TREM-1 の役割}

関節リウマチ（RA）の治療は，TNF 阻害薬に代 表される生物学的製剤によって劇的に進展した。し かしながら，これら生物学的製剂よる単一分子の阻 害は，免疫抑制作用を示すことで，原虫や細菌など の微生物感染を惹起することが問題となりつつあ る.このため, 感染に対する生体防御機能を阻害し ない新たな治療法の開発が重要であると考えられ る. 本セクションでは, 感染症治療に有効な標的分 子 TREM-1 が自己免疫疾患である RA の治療に有
効であることを示唆する所見を紹介する。またヒト とマウスの TREM-1の制御機構の違いについても 解説する ${ }^{10)}$.

\section{1. 関節炎における TREM-1 の発現}

RA に打いて TREM-1 が有効な治療標的分子と なりうるためには, TREM-1 が RA の関節局所に 発現していることが重要である.そこで TREM-1 の発現を検討するため, 滑膜組織に浸潤する CD14 +マクロファージの TREM-1 発現を flow cytometry で検討したところ, TREM-1の発現が認められ た（図 4A)，また，CD14+マクロファージを含む 滑膜組織細胞を TREM-1 アゴニスト抗体で刺激す ると, $\mathrm{TNF} \alpha$ の産生が増強された（図 4B).このこ とから，RAにおいて機能的 TREM-1 が発現して いることが示された.

さらに RA のモデル動物であるコラーゲン誘発関 節炎モデル（CIA）に打ける TREM-1 の発現を検 討した。CIAの滑膜組織から細胞を単離し, TREM-1 の発現を flow cytometry で検討したとこ ろ, CD11b+細胞のほぼ全てが TREM-1 陽性であ った（図 4C). CD11b+細胞はマクロファージお よび好中球を含むが, forward scatter, side scatter の結果から, CD11b + TREM-1+細胞の大多数は マクロファージであった. 以上のことから, 関節炎 組織では, TREM-1+マクロファージが多数存在 することが明らかとなり, 関節炎の病態に TREM1 が関与している可能性が示された. 

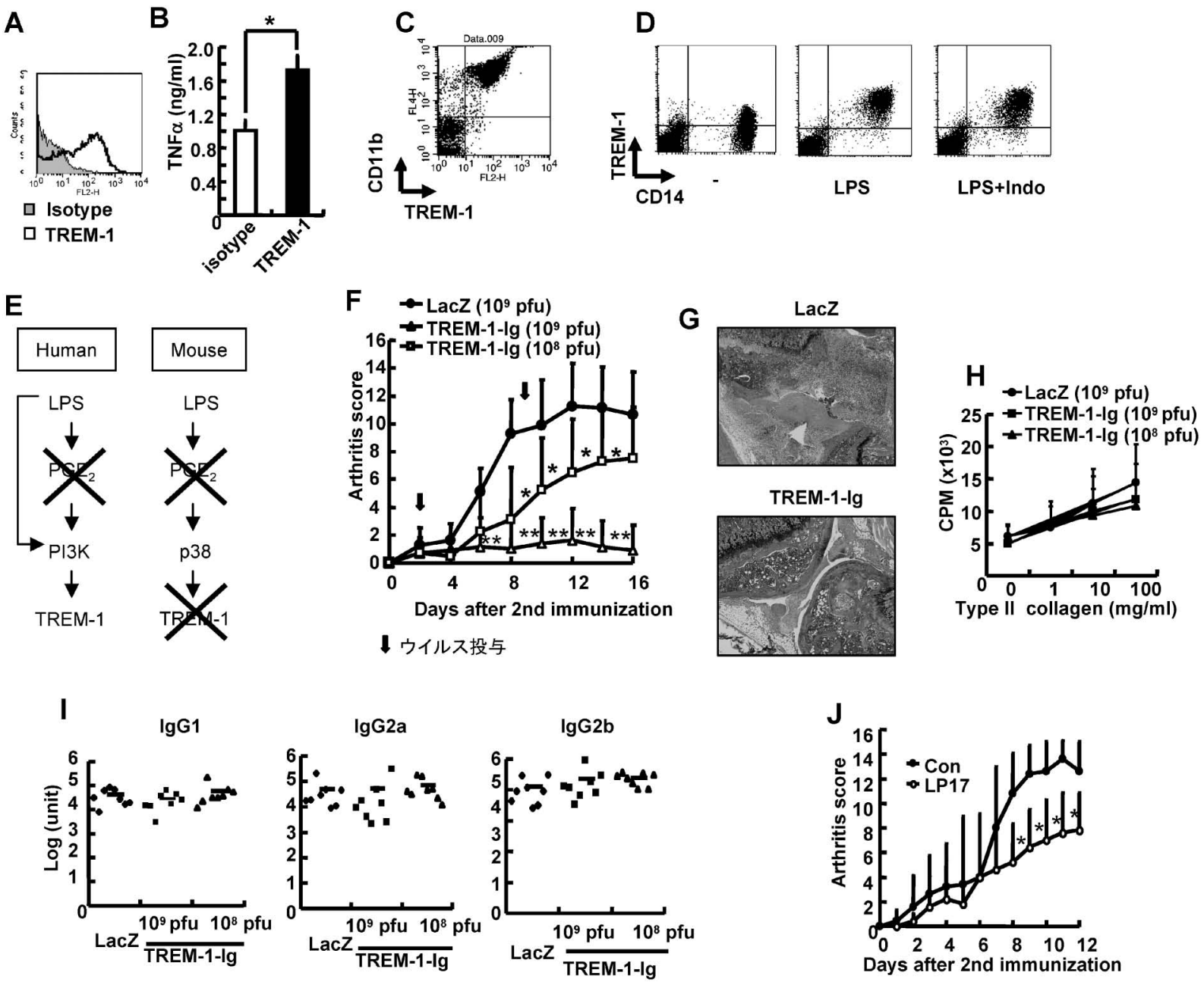

図 4 関節リウマチにおける TREM-1の作用

A. RA 患者由来滑膜組織 CD14+細胞における TREM-1 の発現を flow cytometry で解析. B. 滑膜組織細胞をアゴニスト TREM-1 抗体で刺激し, TNF $\alpha$ の産生を ELISA で測定. C. CIA 由来滑膜組織 CD $11 \mathrm{~b}$ 細胞に抢ける TREM-1 の発現を flow cytometry で解析. D. 末梢血単核球を Indomethacin (COX 阻害剂) 存在下で LPS 刺激し, TREM-1 の発現を flow cytometry で 解析. E. マウスとヒトでの LPS 誘導 TREM-1 発現に打ける PGE 2 依存性の相違. F. TREM-1-Ig or LacZ を組み込んだアデノ ウイルスベクターをCIA マウスにi.v. 投与し, 関節炎スコア測定. G. TREM-1-Ig or LacZ を投与したマウスの関節組織. H. 抗原特異的 T 細胞増殖. I. 抗原特異的抗体価. J. TREM-1 阻害ペプチド（LP17）投与し，関節炎スコア測定.

2. ヒトとマウスにおける TREM-1 発現制御機 構の相違

関節炎では炎症性サイトカイン, 内因性 TLRリ ガンド，PGなどの多彩な炎症性メディエーターが 存在し，これらの分子は TREM-1 発現の制御に関 与していると考えられる。前述の通り，我々はマウ スマクロファージに掠いて, LPS 誘導 TREM-1 発 現は COX 阻害剂存在下で抑制されることを見出し た（図 2B)， $\mathrm{PGE}_{2}$ は様々な炎症局面で誘導される 分子であるため, COX 阻害剂は TREM-1 発現を 減弱し，炎症反応を制御する可能性が想定される. 実際，COX 阻害剤の投与により，関節炎モデルに 対する抑制効果が示されている11)。これは COX 阻 害剂により $\mathrm{PGE}_{2}$ 産生が抑制され，TREM-1 発現
が減弱し，炎症反応が抑制された結果を反映してい る可能性がある.

一方，COX 阻害剤の投与はヒトの関節炎の自然 経過に影響を与えない. COX を介して TREM-1 の発現が制御されているとすると，RAに打いて TREM-1 は重要な役割を果たしていないと解釈さ れる.そこでヒトで TREM-1 が COX 依存的に制 御されているか解析を行った。末梢血単核球を COX 阻害剂存在下で LPS 刺激し TREM-1 の発現 を検討したところ，マウスマクロファージと異なり， TREM-1の発現はタンパクレベルにおいて变動は 認められなかった（図 4D）。つまり，ヒトとマウ スでは TREM-1 は異なる制御を受けていることを 示している. その制御機構の違いをさらに検討する 
ため, 種々のキナーゼ阻害剂を用いて解析を行っ た.ヒトでは TREM-1の発現は PI3K が重要な役 割を果たしていることが明らかとなって打り，我々 も同一の結果を得た。一方，マウスマクロファージ では PI3K ではなく, p38MAPK が重要な役割を果 たしていることが認められた（図 4E）。このように ヒトとマウスでは TREM-1 の発現制御機構が大き く異なり，RA 病態における TREM-1 関与を検討 するためには，TREM-1 を直接阻害することが必 須と考えられる.

\section{TREM-1 阻害による関節炎の効果}

TREM-1 を直接阻害するため, TREM- 1 の細胞 外ドメインに Fc 部分を融合させた TREM-1-Ig を アデノウイルスベクターに組み込んで $\mathrm{AxCA}$ TREM-1-Ig を構築した. コントロールベクターに は AxCA-LacZ を用いた。 AxCA-TREM-1-Ig をマ ウスにi.v. 投与すると, 投与から二日後には血中の TREM-1-Ig 濃度は最大 $(80 \mu \mathrm{g} / \mathrm{ml})$ となり， 1 週 間後まで TREM-1-Ig の濃度は維持された。 また， in vitro でAxCA-TREM-1-Ig を線維芽細胞に感染 させ，TREM-1-Ig を含む培養上清をマクロファー ジと培養し，アゴニスト TREM-1 抗体で刺激する とアゴニスト抗体により誘導される $\mathrm{TNF} \alpha$ の産生 が抑制された。これらのことから，作製した TREM-1-Ig は機能的に作用し, 血中には TREM-1 を阻害するのに十分な量が維持されていることが考 えられた。この AxCA-TREM-1-Ig を II 型コラー ゲン免疫 2 回目から 2 日後に $10^{9} \mathrm{pfu} /$ mouse でi.v. 投与したところ，関節炎スコアはほぼ完全に抑制さ れた. $10^{8} \mathrm{pfu} /$ mouse の投与でも関節炎の抑制効果 は観察された（図 4F)。 . た, 関節の腫脹を測定し たところ，関節炎スコアと同様に腫脹も強く抑制さ れた. さらに, 病理組織学的所見を検討したところ,

AxCA-LacZ 群では著明な炎症細胞浸潤やパンスス 形成，顕著な骨破壊が観察されたが， $\mathrm{AxCA}$ TREM-1-Ig を投与したマウスではいずれも炎症や 関節破壊を示す所見は認められなかった（図 4G). 関節に扮けるサイトカイン発現を定量的 PCR 法で 検討したところ, IL-17, TNF $\alpha, \mathrm{IL}-1 \beta$ の発現はい ずれも TREM-1 阻害群で有意に抑制されていた.

これらのことから，TREM-1 阻害は関節炎の治療 に有効であるとが考えられた。

前述したと打り，TREM-1 は炎症反応を誘導す ることが主な機能である。加えて, TREM-1 活性
化は単球から樹状細胞への分化を促進する作用が報 告されていることから，TREM-1 阻害による関節 炎抑制効果は獲得免疫系へ影響した結果である可能 性があるそそこで， T 細胞に対する影響を検討する ため, AxCA-LacZ 投与群および AxCA-TREM-1Ig 投与群の脾細胞を II 型コラーゲンで刺激したと ころ, 抗原特異的 $\mathrm{T}$ 細胞増殖反応には両群間で差 が認められなかった（図 4H)。 。た，IFN $\gamma$ や IL17 の産生にも差は認められなかった. 次に, B 細 胞反応について検討するため, II 型コラーゲンに 対する抗体価を測定したところ，抗原特異的な $\mathrm{IgG1}, \mathrm{IgG} 2 \mathrm{a}, \mathrm{IgG} 2 \mathrm{~b}$ いずれも AxCA-LacZ 投与群 および AxCA-TREM-1-Ig 投与群間に差は認めら れなかった（図 4I). 以上の結果から，TREM-1の 阻害は抗原特異的な $\mathrm{T} \cdot \mathrm{B}$ 反応への障害を示すこと なく炎症反応応答を抑制したことが示唆された。

\section{TREM-1 阻害ペプチドの効果}

アデノウイルスベクターを用いた遺伝子導入法 は, 安全性の問題があるため臨床応用には多くの問 題がある.このため, 遺伝子導入によらない治療ア プローチを考える必要がある、TREM-1 を阻害す る方法として，未知のリガンドと競合的に作用する ペプチド（LP-17）が報告されている6)。これはリ ガンドが結合すると推測され, ヒトやマウスで保存 されたペプチド部分を合成したものである. 実際, LP-17 を投与すると, エンドトキシンショックや 敗血症モデルの生存率が改善することが報告されて いる.この LP-17を CIA マウスに腹腔内投与する と, 関節炎スコアの改善が認められたことから, TREM-1 の阻害ペプチドは治療方法の一つとなり うると考えられる（図 4J)，但し，ペプチド投与に よる関節炎治療効果は, アデノウイルスベクターを 用いた場合と比較して, 弱いものであった。これ は, ペプチドの安定性による結果を示していること が考えられる。

\section{VI. おわりに}

これまでTREM-1 は感染症において発現が誘導 され, 感染症の増悪に関与していると考えられてき た.しかし，これまでの我々の知見では, 微生物由 来以外の分子である $\mathrm{PGE}_{2}$ によっても TREM-1の 発現は誘導されたことが明らかとなった。 なた, TREM-1 が尿酸結晶誘発性炎症に関与している可 能性も見出した。これらの事実は, 微生物の感染が 
ない，ミエロイド系細胞が主体となる炎症性疾患に TREM-1 が関与していることが考えられ，今後， 様々な疾患において検討されることが望まれる。

本稿では，実際に TREM-1 が自己免疫疾患であ る RA の病態形成に関わりうることを明らかにし， 有望な治療標的分子であることも示した。これは， TREM-1 阻害が感染症にも有効であることを考え 合わせると，TREM-1 を標的とした治療が感染症 を増悪させるリスクの低い，RAの新たな治療戦略 となることが期待される。 今後は，TREM-1 阻害 によって生体防御機能を損なわないことを厳密に評 価していくことが，TREM-1 を標的とした治療の ためには必要である.

TREM-1 のリガンドは血小板上もしくは Gr-1+ 細胞に存在するとの報告があるが，未だ分子の同定 には至っていない.リガンドを同定することは，

TREM-1 本来の機能を in vitro, in vivoに打いて詳 細に解析することができる。それだけでなく，リガ ンドと TREM-1 との結合を阻害する低分子化合物 の開発など，新たな治療法の進展のためにも重要 で, 今後の進展に期待したい.

\section{文献}

1) Bouchon A, Dietrich J, Colonna M.: Inflammatory responses can be triggered by TREM- 1 , a novel receptor expressed on neutrophils and monocytes. J Immunol 164: 4991-4995, 2000.

2) Klesney-Tait J, Turnbull IR, Colonna M.: The TREM receptor family and signal integration. Nat Immunol 7: 1266-1273, 2006.

3) Bleharski JR, Kiessler V, Buonsanti C, Sieling PA, Stenger S, Colonna M, et al.: A role for triggering receptor expressed on myeloid cells-1 in host defense during the early-induced and adaptive phases of the immune response. $J$ Immunol 170: 3812-3818, 2003.

4) Gibot S, Cravoisy A, Levy B, Bene MC, Faure
G, Bollaert PE.: Soluble triggering receptor expressed on myeloid cells and the diagnosis of pneumonia. N Engl J Med 350: 451-458, 2004.

5) Bouchon A, Facchetti F, Weigand MA, Colonna M.: TREM-1 amplifies inflammation and is a crucial mediator of septic shock. Nature 410: 1103-1107, 2001.

6) Gibot $\mathrm{S}$, Kolopp-Sarda MN, Béné MC, Bollaert PE, Lozniewski A, Mory F, et al.: A soluble form of the triggering receptor expressed on myeloid cells -1 modulates the inflammatory response in murine sepsis. J Exp Med 200: 1419-1426, 2004.

7) Schenk M, Bouchon A, Seibold F, Mueller C.: TREM-1-expressing intestinal macrophages crucially amplify chronic inflammation in experimental colitis and inflammatory bowel diseases. J Clin Invest 117: 3097-3106, 2007.

8) Murakami $Y$, Kohsaka $H$, Kitasato $H$, Akahoshi T.: Lipopolysaccharide-induced upregulation of triggering receptor expressed on myeloid cells -1 expression on macrophages is regulated by endogenous prostaglandin $\mathrm{E}_{2} . J$ Immunol 178: 1144-1150, 2007.

9) Murakami Y, Akahoshi T, Hayashi I, Endo H, Kawai S, Inoue M, et al.: Induction of triggering receptor expressed on myeloid cells 1 in murine resident peritoneal macrophages by monosodium urate monohydrate crystals. Arthritis Rheum 54: 455-462, 2006.

10) Yousuke Murakami, Tohru Akahoshi, Naoko Aoki, Masayasu Toyomoto, Nobuyuki Miyasaka, Hitoshi Kohsaka. Intervention of an inflammation amplifier, triggering receptor expressed on myeloid cells 1 , for treatment of autoimmune arthritis. Arthritis Rheum In press.

11) Ochi T, Ohkubo Y, Mutoh S. Role of cyclooxygenase- 2 , but not cyclooxygenase- 1 , on type II collagen-induced arthritis in DBA/ $1 \mathrm{~J}$ mice. Biochem Pharmacol 66: 1055-1060, 2003. 